\title{
除脳ネコの橋排尿中枢に対する化学的刺激の効果に関する研究
}

\author{
秋田大学医学部泌尿器科学教室 (主任:土田正義教授)
}

菅谷公男

\section{THE EFFECTS OF CHEMICAL STIMULATIONS OF THE PONTINE MICTURITION CENTER IN DECEREBRATE CATS}

\author{
Kimio Sugaya \\ Department of Urology, Akita University School of Medicine \\ (Director: Prof. Seigi Tsuchida)
}

In acute decerebrate cats, the pontine micturition center (PMC) was identified by electrical microstimulation, and then putative chemical transmitter agents such as carbachol, acetylcholine, noradrenaline and enkephalin were microinjected into it. The effects of each agent upon micturition reflex were studied. When the bladder was filled with subcritical volume of physiological saline, carbachol $(10 \mathrm{mM}$ or $100 \mathrm{mM}, 0.1 \mu \mathrm{l})$ and acetylcholine $(100 \mathrm{mM}, 0.1 \mu \mathrm{l})$ microinjections into the PMC resulted in micturition. The pattern of changes in bladder pressure and the external urethral sphincter muscle activity was almost identical to those observed during reflex micturition and electrically induced micturition. Upon reflex micturition, carbachol, acetylcholine and noradrenaline microinjections into the PMC resulted in an increase in the maximum bladder pressure and a decrease in bladder capacity, while enkephalin microinjections resulted in a decrease in the maximum bladder pressure and an increase in the bladder capacity. These results indicate that, for the neurons of the PMC, cholinergic inputs act as micturition executing ones, while noradrenergic and enkephalinergic inputs act as micturition modifying ones, exerting facilitatory and inhibitory effects to the PMC, respectively.

\begin{abstract}
要旨：微小電気刺激で同定した除脳ネコの橋排尿中枢に carbachol, acetylcholine, noradrenaline と enkephalinのそれぞれを微量注入し，排尿を誘発できるか否か，また反射性排尿に対してどのような効 果があるのかの 2 点について検討した. 膀胼充満状態での carbachol 注入例 $(10 \mathrm{mM}, 100 \mathrm{mM}$, 各 $0.1 \mu \mathrm{l})$ と acetylcholine 注入例 $(100 \mathrm{mM} ， 0.1 \mu 1)$ で排尿を誘発できた。これらコリン作動性薬剂による排尿は, 反射性排尿や電気刺激誘発排尿時の膀胱内圧曲線と外尿道括約筇筋電図のそれぞれのパターンと一致し た。薬剤注入後に誘発した反射性排尿におよぼす効果としては, コリン作動性薬剤注入例と noradrenaline 注入例では最大膀胱収縮圧は上昇する例が多く, 膀脱容量は減少した。 enkephalin 注入例では 最大膀胼収縮圧は下降し, 膀胱容量は増加した。これらの成績から，橋排尿中权の神経細胞に対して， コリン作動性入力は排尿実行系入力として, noradrenaline 作動性入力と enkephalin 作動性入力はとれ ぞれ排尿促進と抑制の修飾系入力として作用する可能性が考えられた。
\end{abstract}

\section{緒 言}

ネコの橋吻側背外側被蓋部には排尿反射中枢が存在 する ${ }^{1) ~ 6)}$. Barrington ${ }^{1)}$ は慢性ネコの脳幹破壊実験か ら，両側性に破壊すると尿閉になる部位を発見してこ の中枢の存在を示唆した。 その後, Wang and Ranson ${ }^{2)}$ とKuru $5^{3 / 4)}$ は, Barrington が指摘した部位の電気刺 激で膀脱收縮と外尿道括約筋活動の抑制が起こること
を報告している。機能的にこの部位は橋排尿中枢と呼 ばれ, Taber ${ }^{7}$ の四譜によると上小脳脚の内側に位置す る青斑核に相当する。

ネコの青斑核は, 近年 Maeda $ら^{8)}$ とより細胞構築上 から, 背側の狭義の青斑核と腹側の青斑核アルファに 2 分されている. 宮田ら ${ }^{5)}$, 著者ら ${ }^{9) ~ 12) ~}$ は, 除脳ネコや halothane 麻酔ネコの新しい神経核区分に従った青斑 
核アルファに微小電気刺激を加えると排尿が起こるこ とを報告している。しかし，微小電気刺激法では刺激 部位の神経細胞体とその部位を通過する神経線維の両 方を刺激することになる。そのため，青斑核アルファ の電気刺激で誘発する排尿が，神経細胞体と通過線維 のどちらの刺激効果なのかを明らかにすることはでき なかった。

最近，ネコの脳幹内に神経活性物質を注入して，歩 行や姿勢变化を誘発する化学的刺激法 ${ }^{13) ~ 16)}$ が開発さ れた。この方法を用いると，特定の薬剤を微量注入す ることで，その薬剤に対する receptorを持った細胞体 のみを活性化または不活性化できる。著者ら ${ }^{1112)}$ はネ コの青斑核アルファに神経標識物質を注入する実験 で, 青斑核アルファの細胞は大脳皮質から仙髄に至る 広い範囲から直接入力を受けることを明らかにしてい る。著者はこの成績を神経細胞体が含有する神経活性

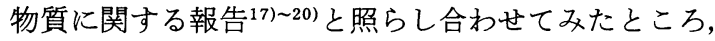
青斑核アルファの細胞は脳脊䯣の多くの領域から acetylcholine, noradrenaline や enkephalin を伝達物 質とする入力を受けることを推定した。 したがって， 青斑核アルファの細胞自体が排尿に関与しているので あれば，これらの薬剤を同部位に微量注入すれば排尿 反射に何らかの変化が生じるはずである。

そこで本実験では，ネコの橋排尿中枢である青斑核 アルファに対し, carbachol, acetylcholine, noradrenaline と enkephalinのそれぞれを微量注入して 排尿反射におよぼす効果を解析したところ，興味ある
知見を得たので報告する。

\section{実験方法}

実験には2.5〜4.5kgのネコ48頭を用いた。 Halothane (2％)で吸入麻酔した後，気管カニューレを挿入 して気道を確保し，両側内頝動脈を結禁した。次に下 腹部を左中切開して膀胱頂部または側壁から 2 本のカ テーテルを膀胖内に挿入し，水注入および残尿量測定 路と膀脱内圧測定路とした．外尿道括約筋筋電図は恥 骨尾側部の筋層を正中切開し, 先端 $2 \mathrm{~mm}$ を露出した直 径 $50 \mu \mathrm{m}$ の 2 本の絶縁ステンレス線を尿道固有横紋筋 (外尿道括約筋) に刺入して導出記録できるようにし, 腹部および恥骨部を閉創した。

図 1 実験模式図.

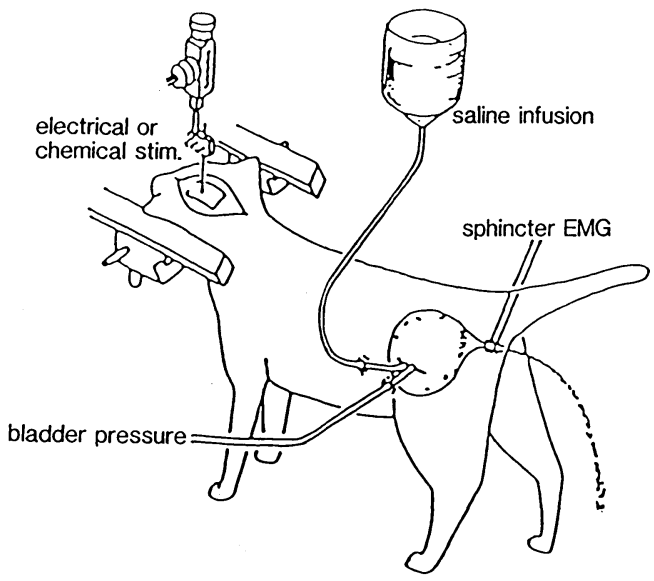

図 2 刺激用電極張り合わせガラス管とその刺入部位. $\mathrm{LC} \boldsymbol{\alpha}$, 青斑核アルファ；PoO, 吻側橋網様核.

\section{A. parasagittal plane}

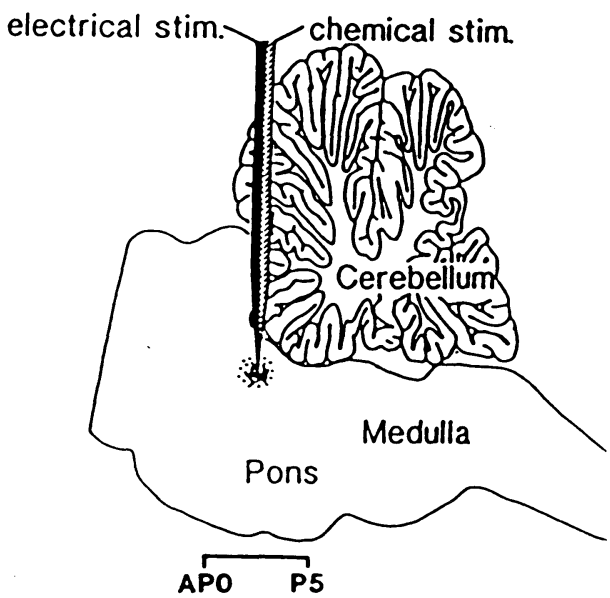

B. frontal plane

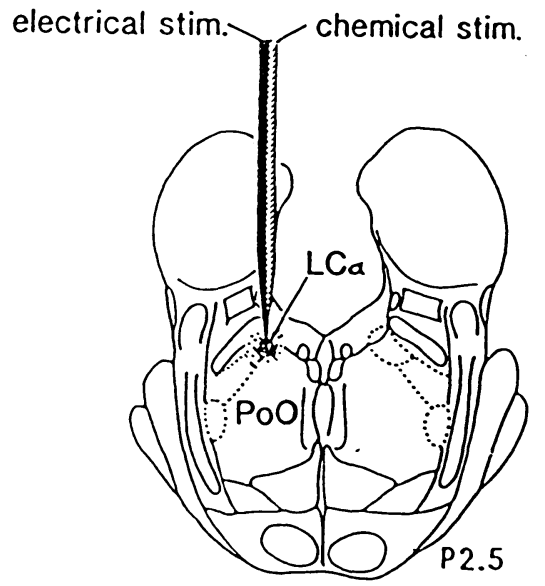


次に, 頭蓋骨を除去して上丘前縁と乳頭体後縁を結 ぶ面で脳幹を切断した。除脳後は麻酔を止め, 骨性テ ントを除去し小脳表面を露出した後, 頭部, 頝椎, 腸 骨を脳定位固定装置に固定して四足立位とした（図 1). 膀脱内圧は statham 社製圧トランスジューサー P50と三栄測器ポリグラフシステム146を用いて外尿 道括約筋筋電図とともに同時記録した。実験中は動物 に温熱ランプを照射して保温した。

化学的刺激には acetylcholinesterase 抵抗性で長時 間作動性の carbachol (carbamylcholine chloride, Sigma) と acetylcholine (acetylcholine chloride, 半 井化学), noradrenaline(Sigma), enkephalin(leucine enkephalin, Sigma）の 4 剂を用いた。これらの薬郕 を $\mathrm{pH} 7.4$ の0.1M 燐酸緩衝生理食塩水に溶解して, そ れぞれを $1 \mathrm{mM}, 10 \mathrm{mM}, 100 \mathrm{mM}$ 濃度の溶液とし, 先端 直径が約 $20 \mu \mathrm{m}$ の微小ガラス管に充填した。微小ガラ ス管には油圧式マニュプレーターを接続して，溶液を 微量注入できるようにした。一方，このガラス管には その先端まで直径 $10 \mu \mathrm{m}$ の絶縁白金イリジゥム線を張 り合わせ，刺激電極として用いた（図 2 ).

（1）反射性排尿の誘発

刺激実験に先だって，48頭の全例で膀胼内へカテー テルを通じて $37^{\circ} \mathrm{C}$ の生理食塩水を約 $30 \mathrm{ml} / \mathrm{min}$ の速度 で点滴注入し，反射性排尿を誘発した。 その際，外尿 道口から生理食塩水が排出された時点で膀胱内への注 入を止めた。 反射性排尿の誘発は 3 回以上行い, 膀胱 容量と残尿量を測定し, 膀脱内圧曲線と外尿道括約筋 筋電困を同時記録してコントロールとした。

（2）橋排尿中枢の同定

48頭の全例で, ガラス管張り合わせ電極を HorsleyClarke 軸に沿って橋吻側背外側部の青斑核アルファ を目標に刺入し， $0.25 \mathrm{~mm}$ 間隔でその部位を電気刺激 しながら橋排尿中枢の部位を検索した。他極は側頭筋 に置いた。電気刺激は反射性排尿を誘発する膀胱容量 の $80 \%$ 量の生理食塩水が膀胱内に貯留している膀胼充 満状態で行った。刺激には持続 $0.2 \mathrm{~ms}$, 頻度 $50 \mathrm{~Hz}$, 強 度10 50 $\mu \mathrm{A}$ の矩形波電流を用い, $3 \sim 5$ 秒間にわ たって通電した。 そして，最も弱い刺激 $(10 \sim 20 \mu \mathrm{A})$ で実際に排尿が誘発される部位を橋排尿中权と同定し た。

（3）化学的刺激による排尿誘発実験

この実験は 20 頭のネコの両側の橋排尿中权に対して 行った。膀胼充満状態で, 1 側の橋排尿中枢に各薬剤 についてそれぞれ $1 \mathrm{mM}$ (各 3 頭), $10 \mathrm{mM}$ (各 $3 \sim 5$
頭), $100 \mathrm{mM}$ (各 $3 \sim 5$ 頭) の濃度溶液 $0.1 \mu 1$ を $20 \sim 30$ 秒かけて注入し，排尿が誘発でさるか否かを観察した。 排尿が起こらない場合は，1 分後さらに0.1 1 1 を追加 注入した。 1 頭での 2 回目の化学的刺激は, 反射性排 尿がコントロールの状態に回復したことを確認してか ら行い, その場合は対側の橋排尿中枢に薬剤を注入し た.

（4）化学的刺激の前後における反射性排尿の誘発実 験

この実験は 28 頭のネコのそれぞれ 1 側の橋排尿中枢 に対して行った. 膀胼空虚時に, 各薬剤の $100 \mathrm{mM}$ 濃度 溶液 (各 6 頭) $0.2 \mu 1$ を $20 \sim 30$ 秒間で橋排尿中枢に注入 し, その前後で 5 分間隔に膀胼内一注水して反射性排 尿を誘発した。 そして, 薬剂注入前後における反射性 排尿時の膀脱容量, 膀胱内圧と外尿道括約筋筋電図を

図 3 反射性排尿, 電気刺激誘発排尿と carbachol 誘 発排尿に抢ける膀胼内圧曲線 $(\mathrm{CMG})$ と外尿道括約 筋筋電㘡 $(E M G)$. 説明本文.
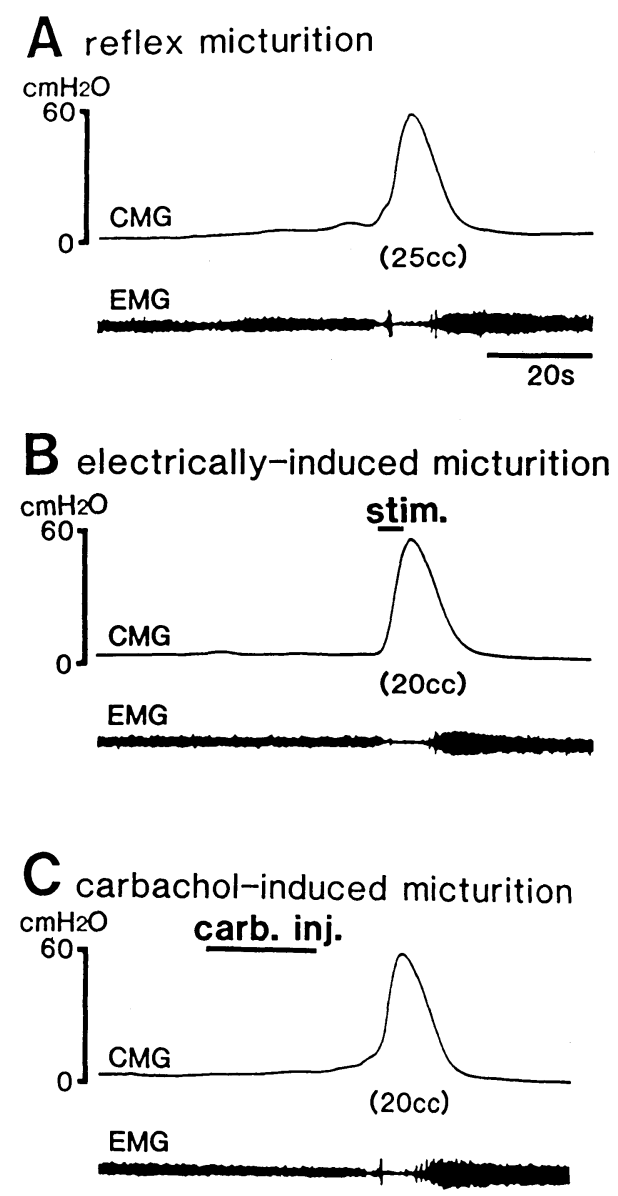
経時的に記録した。 またコントロール実験として溶 解液である $0.1 \mathrm{M}$ 燐酸緩衝生理食塩水 $0.2 \mu 1$ の注入実 験も 4 頭で行った.

（5）刺激部位の組織学的同定

実験終了後は橋排尿中枢に白金イリジゥム線を通じ $\tau 50 \mu \mathrm{A} ， 30$ 秒の直流通電を行い，微小破壊巣を作製し た。脳幹を取り出し $10 \%$ ホルマリンで固定した後， 50 $\mu \mathrm{m}$ の連続凍結横断切片とし, 組織学的に微小破壊巣 の局在部位を同定した。

\section{結果}

（1）反射性排尿

コントロールとしての反射性排尿は，図 $3 \mathrm{~A}$ に示す ように膀脱収縮時に外尿道括約筋活動が抑制された。

このような膀胼尿道協調運動パターンは全例で認めら れ，また，いずれの例でも残尿はなかった。 3 回以上 の反射性排尿時の膀胱容量, 最大膀胼収縮圧, 膀胱収 縮時間は各個体毎にほぼ一定していた。しかし，これ らのパラメーターは個体間の変動が大きく, 膀脱容量 は $8 \sim 38 \mathrm{ml}$, 最大膀胱収縮圧は $33 \sim 80 \mathrm{cmH}_{2} \mathrm{O}$, 膀胱収 縮時間は15〜45秒の幅があった。
（2）電気刺激誘発排尿

$10 \sim 20 \mu \mathrm{A}$ の電気刺激で排尿が誘発できた領域は, Horsley-Clarke 軸上 P 2.5 3.0, LR 2.25 2.5, H2.25〜H-2.5の領域であった。 また，いずれの例も電 気刺激開始から1 1.5秒後に排尿が始まり，残尿はな かった。電気刺激で誘発した排尿時の膀胱内圧曲線と 外尿道括約筋筋電図のパターンも，図 $3 \mathrm{~B}$ に示すよう に同一個体では反射性排尿時のそれぞれのパターンと ほぼ一致した。

（3）化学的刺激による誘発排尿

橋排尿中枢へ carbachol を注入すると, $10 \mathrm{mM}$ 濃度 溶液を注入した 5 頭中 3 頭と $100 \mathrm{mM}$ 濃度溶液注入の 5 頭の全例で, 注入開始から2 40秒後に排尿が誘発で きた。これらの例では残尿はなかった。しかし，10mM 濃度溶液を注入した残る 2 頭と $1 \mathrm{mM}$ 濃度溶液注入の 3 頭では排尿は起こらなかった。 $100 \mathrm{mM}$ 濃度溶液の 注入で誘発した排尿時の膀胱内圧曲線と外尿道括約筋 筋電図を図 $3 C$ に示す．図 3 の各膀胼内圧曲線と外尿 道括約筋筋電図は同一個体から記録したが，図 $3 \mathrm{C}$ の carbachol 誘発排尿時のパターンは, 図 3A の反射性

図 4 橋排尿中枢への化学的刺激が反射性排尿に招よぼす効果. A. carbachol 注入

例；B. acetylcholine 注入例；C. noradrenaline 注入例；D. enkephalin 注入 例. 説明本文.

BEFORE

A

$\mathrm{cmH} 2 \mathrm{O}$

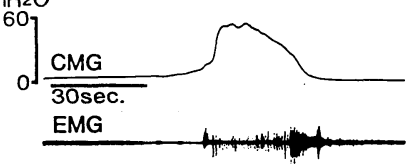

B

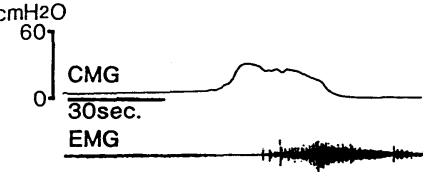

C

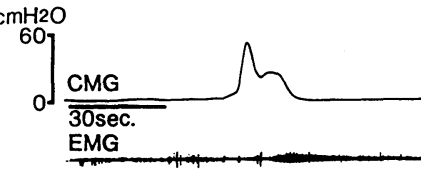

D

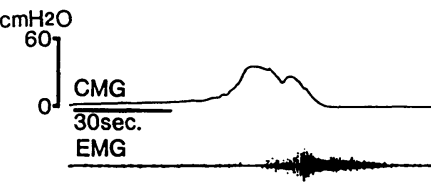

IMMEDIATELY AFTER

15MIN. AFTER

\section{Carbachol}

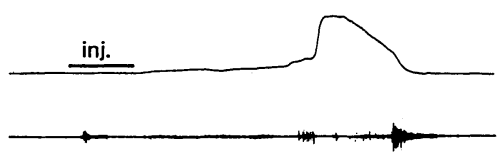

Acetylcholine

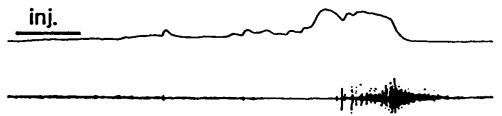

Noradrenaline

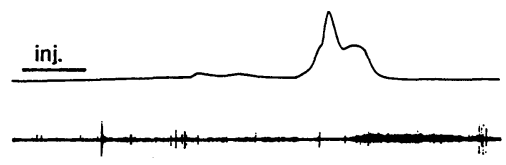

Enkephalin

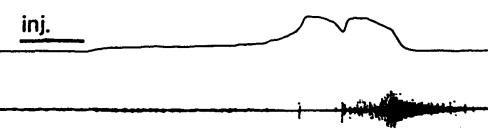

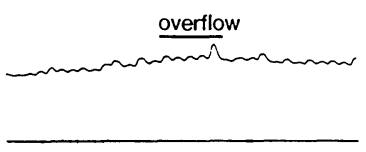
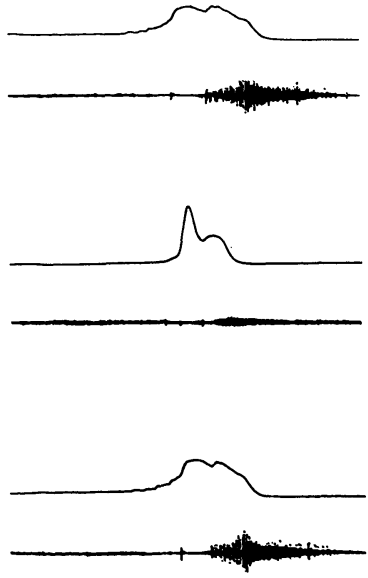
排尿時と図 3B の電気刺激誘発排尿時の各パターンと ほぼ一致した。これらの 3 種類の刺激で誘発した排尿 パターンは，他の個体でもほぼ一致した。

3 種類の濃度の acetylcholine（各 3 頭）を注入した 例で排尿を誘発したのは，100mM 濃度を注入した 1 例のみであった。この acetylcholine の注入で誘発し た排尿は, 注入開始から 30 秒後に起こり, 残尿はなかっ た。この排尿時の膀胱内圧曲線と外尿道括約筇筋電図 のパターンは反射性排尿時のそれぞれのパターンと泀 ぼ一致した。

noradrenaline と enkephalin に注入した例では排 尿は起こらなかった。また，1回目の化学的刺激で排 尿しない例は， 1 分後に同薬剤を追加注入しても排尿 せず, 膀胱内圧にも変化がなかった。

（4）反射性排尿に対する化学的刺激の効果

化学的刺激の前後に誘発した反射性排尿時の膀胱内 圧曲線と外尿道括約筋筋電図を図 4 に示す。1 側の橋 排尿中枢に対して化学的刺激を反復した場合は，1回 目の化学的刺激後の膀胱容量と最大膀胱収縮圧の变化 に比べて 2 回目のそれらの変化は小さかった。 そのた め, 1 回目の化学的刺激の結果のみを評価の対象とし た.

carbachol 注入の効果：図 4A は carbachol の注入 例であるが，注入前に比べて直後の反射性排尿時の膀 脱内圧曲線と外尿道括約筋筋電㘡のパターンに大きな 变化はなかった。しかし，反射性排尿を誘発する膀胼 容量は $25 \mathrm{ml}$ から $20 \mathrm{ml}$ へと減少した. 対象 6 例の平均 膀胱容量とその標準偏差は注入前 $18.7 \pm 6.9 \mathrm{ml}$ から注 入後には $13.5 \pm 5.2 \mathrm{ml}$ と減少し, 最大膀胼収縮圧は $54.7 \pm 11.1 \mathrm{cmH}_{2} \mathrm{O}$ から注入後 $59.5 \pm 11.7 \mathrm{cmH}_{2} \mathrm{O}$ と
上昇した(表 1)。乙かし，これらの值の間に統計学的 な有意差（ $\mathrm{t}$ 検定）はなかった。 carbachol の注入から 5 分以後は膀胱収縮が起こらなくなり，外尿道括約筋 活動も消失して外尿道口から生理食塩水の溢流が起 こった。この溢流性尿失禁の状態は $1 \sim 2$ 時間続き， その後徐々に排尿機能が回復して注入前の状態に戻っ た。

acetylcholine 注入の効果：図 4B は acetylcholine 注入による反射性排尿の変化である. acetylcholine 注 入直後は, 膀胼内への注水に伴い膀脱内圧が小刻みに 上下する過活動性膀胱のパターンであった，対象 6 例 の平均膀胱容量は注入前 $26.4 \pm 12.0 \mathrm{ml}$ から注入後 $21.8 \pm 10.9 \mathrm{ml}$ と減少したが, 最大膀胱収縮圧は $55.7 \pm$ $12.2 \mathrm{cmH}_{2} \mathrm{O}$ から $56.0 \pm 12.1 \mathrm{cmH}_{2} \mathrm{O}$ とほとんど変化 しなかった(表 1 )。この膀胱容量の変化は注入直後の 反射性排尿にの久認められ，5分以後に誘発した反射 性排尿は注入前の状態に回復した。

noradrenaline 注入の効果: 図 4C drenaline 注入による反射性排尿の変化である. noradrenaline 注入例でも注入直後の膀胱内圧曲線と外尿 道括約筋活動の基本的パターンは変わらなかった。対 象 6 例の平均膀脱容量は注入前 $17.7 \pm 8.0 \mathrm{ml}$ から注入 後 $10.8 \pm 6.7 \mathrm{ml}$ と有意 $(\mathrm{p}<0.05)$ に減少した（表 1$)$. 最大膀胱收縮圧は $54.7 \pm 11.9 \mathrm{cmH}_{2} \mathrm{O}$ から $58.8 \pm 13.0$ $\mathrm{cmH}_{2} \mathrm{O}$ 一と上昇したが，この収縮圧に有意差はな かった。これらの変化は注入直後の反射性排尿で最も 大きく，10〜15分後には注入前の状態に回復した.

enkephalin 注入の効果: 図 4D は enkephalin 注入 による反射性排尿の変化である. enkephalin 注入例で も注入前後の膀脱内圧曲線と外尿道括約筋筋電図のパ

表 1 橋排尿中枢への化学的刺激の前後に誘発した反射性排尿における膀胼容量と最 大膀脱収縮圧.

\begin{tabular}{|c|c|c|c|c|c|}
\hline \multirow{2}{*}{ Chemical Agent } & \multirow{2}{*}{$n$} & \multicolumn{2}{|c|}{ Bladder Capacity $(\mathrm{ml} \pm$ S.D. $)$} & \multicolumn{2}{|c|}{ Maximum Bladder Pressure $\left(\mathrm{cmH}_{2} 0 \pm S . D.\right)$} \\
\hline & & before & after & before & after \\
\hline Carbachol & 6 & $18.7 \pm 6.9$ & $13.5 \pm 5.2$ & $54.7 \pm 11.1$ & $59.5 \pm 11.7$ \\
\hline Acetylchol ine & 6 & $26.4 \pm 12.0$ & $21.8 \pm 10.9$ & $55.7 \pm 12.2$ & $56.0 \pm 12.1$ \\
\hline Noradrenal ine & 6 & $17.7 \pm 8.0$ & $10.8 \pm 6.7^{\star}$ & $54.7 \pm 11.9$ & $58.8 \pm 13.0$ \\
\hline Enkephal in & 6 & $13.9 \pm 7.6$ & $21.9 \pm 7.2^{\star}$ & $64.7 \pm 14.2$ & $49.3 \pm 21.3$ \\
\hline Phosphate buffered saline & 4 & $16.3 \pm 5.8$ & $16.3 \pm 5.3$ & $60.5 \pm 6.4$ & $59.5 \pm 7.1$ \\
\hline
\end{tabular}

$\star P<0.05$ 
図 5 橋排尿中枢への化学的刺激直後に誘発した反射 性排尿に打ける膀脱容量と最大膀脱収縮圧の变化 率。斜線は図中の全ての点から求めた回帰直線 $\mathrm{Y}=-0.258 \mathrm{X}+124(\mathrm{r}=-0.767, \mathrm{p}<0.001)$ を示す.

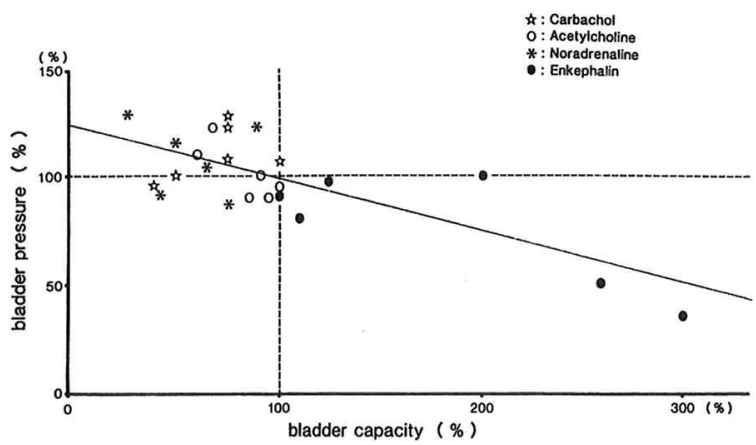

ターンは基本的に変わらなかった，対象 6 例の平均膀 脱容量は注入前 $13.9 \pm 7.6 \mathrm{ml}$ から注入後 $21.9 \pm 7.2 \mathrm{ml}$ と有意 $(p<0.05)$ に増加した（表 1$)$ ，最大膀胱収縮 圧は64.7士 $14.2 \mathrm{cmH}_{2} \mathrm{O}$ から $49.3 \pm 21.3 \mathrm{cmH}_{2} \mathrm{O}$ と下 降したが有意差はなかった。これらの変化は注入直後 の反射性排尿で最も大さく，15分後には注入前の状態 に回復した。

燐酸緩衝生理食塩水注入の効果：溶解液である燐酸 緩衝生理食塩水のみの注入例では，注入前後の反射性 排尿時の膀胼容量と最大膀胼収縮王に変化はなかった (表 1 ).

各薬剂注入による効果の比較：図 5 には化学的刺激 前の反射性排尿時の膀胼容量と最大膀胱収縮圧をそれ ぞれ100\%とし,各薬剤による化学的刺激直後の反射性 排尿時のそれぞれの值の変化を百分率で示してある。 carbachol, acetylcholine と noradrenaline 注入例で は膀胱容量は減少し，最大膀脱収縮圧は上昇する例が 多かった. enkephalin 注入例では逆に, 膀胱容量は増 加し最大膀脱収縮圧は下降した，図 5 のすべての点か ら回帰直線を求めると, $\mathrm{Y}=-0.258 \mathrm{X}+124$, 相関係数 $\mathrm{r}=-0.767(\mathrm{p}<0.001, \mathrm{t}$ 検定 $)$ となり, 膀胱容量, 最 大膀胱収縮圧ともに $100 \%$ の点, つまり化学的刺激前の 膀胼容量と最大膀胱収縮王の值の近傍を通る直線と なった。

(5) 組織学的に同定した化学的刺激部位

化学的刺激後, 橋排尿中枢に作製した電気破壊巣は, Horsley-Clarke 軸上 P 2.5〜3.0の青斑核アルファ内 またはその周囲の神経核との境界域にあった（図6）。

$$
\text { 考案 }
$$

中枢神経機構の細胞構成に関しては，ある行動のた
図 6 化学的刺激部位に作製した電気破壊巣. 図 3 と 同一ネコ、橋吻側背外側部 (P3) の青斑核アルファ (LC $\alpha)$ 内に破壊巣を認める.

$\mathrm{BC}$, 上小脳脚： LC, 青斑核: $\mathrm{LC} \alpha$, 青斑核アル ファ：LSC，青斑下核：mV，三叉神経中脳路： PBM, 内側脚傍核：PoO, 吻側橋網様核。

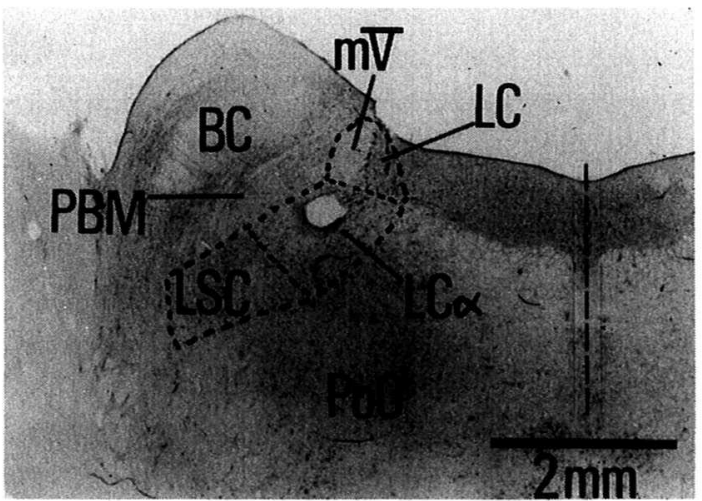

めの神経機構は実行系としての主ニューロン鎖と, 主 ニューロン鎖に投射してその機能を調節する修飾系 ニニーロンで構成されるとする考方がある ${ }^{211}$. 本実 験では carbachol, acetylcholine といったコリン作動 性薬剂を橋排尿中枢へ微量注入することで排尿を誘発 できたが，この考え方に基づくと，青斑核アルファの コリン受容性細胞は排尿実行系としての主ニューロン 鎖の構成要素であることが考学られる，また，これら の細胞へのコリン作動性入力も排尿実行系の 1 つであ り，青斑核のコリン受容性細胞を賦活して脳幹・脊髄 の排尿実行系を作動させる引金となることを示唆して いる.

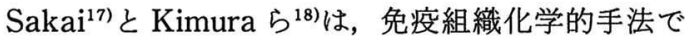
ネコの青斑核アルファにコリン受容性細胞の存在する ことを明らかにしているが，これらの細胞へ投射する コリン含有細胞の正確な局在部位までは追求していな い. 著者ら ${ }^{1112)}$ は, 青斑核アルファが脳幹網様体, 中脳 中心灭白質, 脊髅中間灰白質から多くの入力を受ける ことを HRP 法を用いて明らかにしており，また，これ らの領域には acetylcholine 含有細胞の存在すること が知られている17) 20)。したがって，青斑核アルファの 細胞は排尿を誘発するコリン作動性入力をこれらの領 域のいずれかから受けると考学られる。

本実験における化学的刺激が反射性排尿におよぼす 効果をみると, carbachol 注入は，排尿促進の後，抑制 といら 2 相性の効果を示した。青斑核アルファの腹内 側部には広い範囲を占める吻側橋網様核があるが，こ 
の領域にもコリン受容性細胞の存在することが知られ

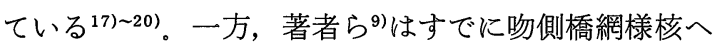
carbachol を注入すると，注入直後から排尿反射が抑 制されることを報告している。したがって, acetylcholinesterase で分解される acetylcholine の注入効 果が排尿促進のみであったことと, carbachol が同酵 素に抵抗性の長時間作動性薬剤であることを考兄合わ せると，青斑核アルファへ注入した carbachol が 5 分 後には吻側橋網様核へ拡散して排尿抑制効果が現れた と考えられる。

ネコの青斑核アルファの細胞は, ラットでいう noradrenaline 含有細胞の group A1 14の領域からも入 力を受け1111219202022，さらに青斑核アルファへの入力 部位の中脳中心灰白質, 外側脚傍核, 前庭神経核複合 体と脊䯣中間灰白質には enkephalin 含有細胞が存在 する1112192020)。今回検討した noradrenaline による化 学的刺激実験では，その $100 \mathrm{mI}$ 濃度溶液の注入でも 排尿を誘発できなかったが，反射性排尿に対しては排 尿を誘発する膀胱容量の減少と最大膀胱収縮圧の上昇 といら排尿促進効果があった。一方, enkephalin によ る化学的刺激実験では膀胱容量の増加と最大膀胼収縮 圧の下降という排尿抑制効果があった。これらの成績 から，青斑核アルファにはコリン受容性細胞の他に， noradrenaline 受容性細胞や enkephalin 受容性細胞 の存在することが考兄らる。そして, これらの細胞 への noradrenaline 作動性入力や enkephalin 作動性 入力は，排尿実行系に対してそれぞれ促進的，抑制的 に修飾作用すると考えられる。

本成績で注目されるのは, 各楽剂による化学的刺激 の反射性排尿におよぼす効果が，刺激前の反射性排尿 時の膀胱容量と最大膀脱収縮圧の值から, 膀脱容量の 減少と最大膀胼収縮圧の上昇といら排尿促進方向とそ の逆の排尿抑制方向へ引かれた回帰直線上に移動した ことである。このことは，青斑核アルファの細胞には 蓄尿時にも排尿時にも排尿促進と抑制の両方の入力が あり，膀脱の充満に伴って増加する促進性入力と減少 する抑制性入力が交差した時点で排尿を誘発すること を示唆している。つ方，化学的刺激に基づく外部か らのある種の入力は, 同種の本来の入力に加算された ため，相反する入力と交差する点が移動し，結果とし て排尿促進または抑制の効果が現れたと言える。そし て, 今回検討した薬剤に限って言えば，正常な状態で は青斑核アルファの細胞に対してコリン作動性や noradrenaline 作動性入力が相対的に大きい状態で排
尿を誘発し，蓄尿時には enkephalin 作動性入力が相 対的に大きい状態となっていることが考兄られる。

以上の一連の成績は, 青斑核アルファの細胞が排尿 の誘発だけでなく，排尿中の膀胱収縮力にも関与する ことを示している。また, 青斑核アルファの細胞に対 してコリン作動性入力は排尿実行系入力として, noradrenaline 作動性入力と enpephalin 作動性入力はそ れぞれ排尿促進と抑制と修飾系入力として作用する可 能性が考学られる。

\section{結 論}

微小電気刺激で同定した除脳ネコの橋排尿中枢に, carbachol, acetylcholine, noradrenaline と enkephalin をそれぞれ微量注入し，排尿を誘発できるか否 か，また，反射性排尿に対してどのような効果がある のかの 2 点について検討した。

1. Carbachol 注入例と acetylcholine 注入例で, 反 射性排尿や電気刺激誘発排尿時の膀胱内圧曲線, 外尿 道括約筋筋電図と同一パターンの排尿を誘発できた。

2。薬剤注入後に誘発した反射性排尿に扣よぼす効 果としては, carbachol, acetylcholine, noradrenaline の注入例で排尿促進効果を示し, enkephalin 注入例で は排尿抑制効果を示した。

3。これらの結果から, 橋排尿中枢の神経細胞に対し てコリン作動性入力は排尿実行系入力として, noradrenaline 作動性入力と enkephalin 作動性入力はそ れぞれ排尿促進と抑制の修飾系入力として作用する可 能性が考えられた。

稿を終えるにあたり, 御指導, 御校閲下さった恩師土田正 義教授に深く感謝する。 また, 本研究に際し, 直接御指導, 御校閲下さった旭川医科大学生理学第 2 講座の恩師森茂美 教授をはじめ, 同教室員諸兄に深く感謝する。

本論文の要旨の一部は, 第64回日本生理学会大会, 第10回 神経科学学術集会ならびに第17回 International Continence Society に於て発表した。また, 本研究は, 昭和61年 度文部省科学研究費奖励研究 (A)（61770087）によるもの であることを付記する。

\section{文献}

1) Barrington, F.J.F.: The effect of lesions of the hind-and mid-brain on micturition in the cat. Quart. J. Exp Physiol., 15, 81-102, 1925.

2) Wang, S.C. and Ranson, S.W.: Autonomic responses to electrical stimulation of the lower brain stem. J. Comp. Neurol., 71, 437-455, 1939.

3) Kuru, M., Koyama, Y. and Ozaki, H. : Part of the brain stem controlling the tone of external 
urethral sphincter. Proc. Jap. Acad., 39, 530 $-533,1963$.

4) Kuru, M. and Yamamoto, H.: Fiber connections of the pontine detrusor nucleus (Barrington). J. Comp. Neurol., 123, 161-186, 1964.

5）宮田昌伸, 森 茂美, 黒田一秀：排尿に拈ける仙䯣 及び橋の機能的役割に関する研究. 日泌尿会誌, $75,826-835,1984$.

6) Holstege, G., Griffiths, D., de Wall, H. and Dalm, E.: Anatomical and physiological observations on supraspinal control of bladder and urethral sphincter muscles in the cat. J. Comp. Neurol., 250, 449-461, 1986.

7) Taber, E.: The cytoarchitecture of the brain stem of the cat. I. Brain stem nuclei of cat. J. Comp. Neurol., 116, 27-70, 1971.

8) Maeda, T., Pin, C., Salvert, D., Ligier, M. et Jouvet, M. : Les neurones contenant des catecholamines du tegmentum pontique et leurs voies de projection chez le chat. Brain Res., 57, 119-152, 1973.

9) Sugaya, K., Mori, S., Nishizawa, O., Noto, H. and Tsuchida, S.: Chemical stimulation of the pontine micturition center and the nucleus reticularis pontis oralis. Neurourol. Urodyn, 6 , 143-144, 1987.

10) Sugaya, K. and Matsuyama, K.: Effects of chemical stimulation to the pontine micturition center of the cat. Neurosci. Res., Suppl., 5, S23, 1987.

11）菅谷公男, 森 茂美, 土田正義：橋排尿中枢におけ る入出力神経構築の同定. 第 1 報. 入力路を中心と 乙て. 日泌尿会誌，投稿中.

12）菅谷公男, 森 茂美, 土田正義：橋排尿中枢に打け る入出力神経構築の同定. 第 2 報. 出力路を中心と して. 日泌尿会誌, 投稿中.

13) Baghdoyan, H.A., Monaco, A.P., RodrigoAngulo, M.L., Assens, F., McCarley, R.W. and Hobson, J.A.: Microinjection of neostigmine into the pontine reticular formation of cats enhances desynchronized sleep signs. J. Pharmacol. Exp. Ther., 231, 173-180, 1984.
14) Garcia-Rill, E., Skinner, R.D. and Fitzgerald, J. A.: Chemical activation of the mesencephalic locomotor region. Brain Res., 330, 43-54, 1985.

15) Takakusaki, K., Ohta, Y. and Mori, S.: Neuronal mechanisms involved in postural suppression in decerebrate, reflex standing cats. Neurosci. Res., Suppl., 5, S132, 1987.

16) Mori, S., Ohta, Y., Takakusaki, K., Matsuyama, K. and Sugaya, K.: Pontomedullary and spinal mechanisms of postural suppression in decrebrate reflex standing cats. J. Neurosci. Methods., in press.

17) Sakai, K.: Some anatomical and physiological properties of pontomesencephalic tegmental neurons with special reference to the PGO waves and postural atonia during paradoxical sleep in the cat. In The reticular formation revisited, edited by Hobson, J.A. and Brazier, M.A.B., p. 427-447, Raven Press, New York, 1980.

18) Kimura, H., mcGeer, P.L., Peng, J.H. and McGeer, E.G. : The central cholinergic system studied by choline acetyltransferase immunohistochemistry in the cat. J. Comp. Neurol., 200, 151-201, 1981.

19) Nieuwenhuys, R.: Survey of chemically defined cell groups and pathways. in Chemoarchitecture of the brain, edited by Nieuwenhuys, R., p. 7-113, Springer-Verlag, Berlin, 1985.

20）河井百合子, 木山博資, 窪田芝之, 高見健治, 山野 真利子, 阪中雅広：神経系に拈ける各種活性物質 の局在. 塩谷弥兵衛 編, 目で見る脳の構造と活性 物質. p. 143-189，厚生社，大阪， 1985 .

21）前田敏博：脳幹のアミン系とコリン系の形態学. 神経進歩，30，302-313，1986.

22) Sakai, K., Touret, M., Salvert, D., Leger, L. and Jouvet, M.: Afferent projections to the cat locus coeruleus as visualized by the horseradish peroxidase technique. Brain Res., 119, 21-41, 1977.

（1988年 2 月 16 日受理） 